\title{
Pengaruh Hafalan Al-Qur'an terhadap Prestasi Belajar Matematika Siswa MTs
}

\author{
Dewi Dwi Adiwijayanti ${ }^{1 *}$, Heni Purwati ${ }^{2}$, Sugiyanti ${ }^{3}$ \\ 1,2,3 Universitas PGRI Semarang \\ *dewidwia1@gmail.com
}

\begin{abstract}
ABSTRAK
Menghafal Al-Qur'an merupakan suatu proses mengingat, di mana seluruh materi ayat (rincian bagian-bagiannya seperti fonetik, waqaf, dan lain-lainnya) harus diingat secara sempurna. Salah satu manfaat menghafal Al-Qur'anadalah penguatan otak dimana mereka harus teliti dan jeli dalam membedakan ayat-ayat yang memiliki kemiripan redaksi. Penelitian ini bertujuan untuk mengetahui pengaruh hafalan Al-Qur'an terhadap prestasi belajar matematika siswa MTs. Jenis penelitian ini adalah penelitian kuantitatif. Sampel penelitian ini adalah siswa kelas VIII B MTs Yanbu'ul Qur'an 2 Muria tahun ajaran 2019/2020. Pengumpulan data dilakukan dengan dokumentasi, tes berupa tes tertulis prestasi belajar, dan non tes berupa lembar observasi hafalan Al-Qur'an. Kesimpulan dari penelitian ini adalah terdapat pengaruh positif dan signifikan antara hafalan Al-Qur'an terhadap prestasi belajar matematika siswa MTs Yanbu'ul Qur'an 2 Muria, hal ini ditunjukkan dengan nilai r sebesar 0,589 dengan sumbangan efektif sebesar 34,7\% sedangkan 65,3\% ditentukan oleh faktor lain.
\end{abstract}

Kata kunci: hafalan Al-Qur'an, prestasi belajar.

\begin{abstract}
Memorizing Al-Qur'an is a process of remembering, where all the verse material (details of its parts such as phonetics, waqaf and other) must be memorized perfectly. One of the benefits of memorizing Al-Qur'an is the strengthening of the brain where they must be careful and observant in differentiate verses that have similar redaction. This study aimsto determine the effect of memorizing Al-Qur'an on mathematics learning achievement of MTs students. This research is quantitative research. The sampel of this research are students of class VIII B MTs Yanbu'ul Qur'an 2 Muria in the academic year 2019/2020. Data collection using documentation, test in the form of written test of learning achievement and non-test in the form of memorizingAl-Qur'an memorization sheet. The conclusion of this study is that there was a positive and significant influence between memorization ofAl-Qur'an on mathematics learning achievement of students of MTs Yanbu'ul Qur'an 2 Muria, indicated by the valuer of 0.589 for an effective contribution of $34.7 \%$ while $65.3 \%$ is determined by other factors. Keywords: Memorizing the Qur'an, learning achievement.
\end{abstract}




\section{PENDAHULUAN}

Al-Qur'an merupakan sumber petunjuk dan pedoman hidup bagi umat islam di seluruh dunia. Al-Qur'an adalah kitab suci yang terakhir yang diturunkan Allah swt kepada Nabi Muhammad saw melalui malaikat Jibril a.s. dan sebagai penyempurna dari kitab-kitab sebelumnya. Al-Qur'an diturunkan secara berangsur-angsur kepada Nabi Muhammad S.A.W. dalam rentang waktu 22 tahun 2 bulan 22 hari. Hukum, nasihat, dan suri tauladan jelas diatur di dalam Al-Qur'an sehingga mereka yang mempelajari dan mengamalkannya mendapatkan ketentraman dalam hidup. Mengingat betapa pentingnya Al-Qur'an bagi manusia maka suatu kewajiban bagi setiap muslim untuk mempelajari Al-Qur'an. Memperkenalkan dan menanamkan nilai-nilai Al-Qur'an harus dilakukan sejak dini. Membaca Al-Qur'an merupakan langkah awal kemudian dengan cara memahami maknanya lalu dilanjutkan dengan mengamalkannya

Menurut Subandi (2010:2) menghafal Al-Qur'an bukan pula semata-mata menghafal dengan mengandalkan kekuatan memori, akan tetapi termasuk serangkaian proses yang harus dijalani oleh penghafal Al-Qur'an setelah mampu menghafalkan Al-Qur'an secara kuantitas. Menghafal Al-Qur'an merupakan suatu proses mengingat, di mana seluruh materi ayat (rincian bagian-bagiannya seperti fonetik, waqaf, dan lain-lainnya) harus diingat secara sempurna. Dalam menghafal Al-Qur'an memerlukan konsetrasi dan daya ingat yang sangat tajam. Keistimewaan menghafal Al-Qur'an juga terletak pada berat, unik, dan panjangnya proses yang akan dilalui. Penghafal Al-Qur'an berkewajiban untuk menjaga hafalannya, memahami apa yang dipelajarinya dan bertanggung jawab untuk mengamalkannya.

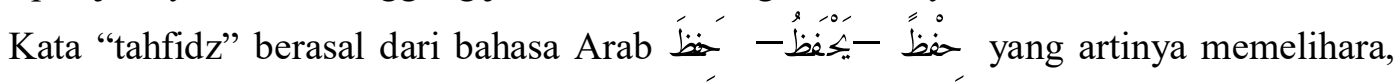
menjaga, dan menghafal (Shirazy, 2018: 91). Secara istilah menurut Abdur Rabi Nawabudin (dalam Mahmudah, 2016) hafal mengandung dua pokok, yaitu hafal seluruh Al-Qur'an serta mencocokkannya dengan sempurna dan senantiasa terus menerus dan sungguh-sungguh dalam menjaga hafalan dari lupa. Sehingga seseorang belum dikatakan hafal apabila ia tidak mampu mengucap kembali suatu materi yang sudah dipelajari.

Salah satu manfaat menghafal Al-Qur'anadalah penguatan otak. Salah satu faktor penguatan intelektual seseorang dalam menghafal adalah ketika seorang penghafal jeli dengan keberadaan ayat-ayat yang mempunyai kemiripan redaksi. Hal ini mengharuskan untuk teliti dalam membedakan setiap ayat yang mempunyai kemiripan redaksi pada surahnya masingmasing.

Prestasi belajar merupakan serangkaian kalimat yang terdiri dari dua kata, yaitu prestasi dan belajar di mana kedua kata tersebut saling berkaitan dan diantaranya mempunyai pengertian yang berbeda. Prestasi itu tidak mungkindicapai atau dihasilkan oleh seseorang selama tidak melakukan kegiatan dengan sungguh-sungguh atau dengan perjuangan yang gigih. Dalam kenyatannya untuk mendapatkan prestasi tidak semudah membalikan telapak tangan, tetapi harus penuh perjuangan dan berbagai rintangan dan hambatan yang harus dihadapi untuk mencapainya. Hanya dengan keuletan, kegigihan, dan optimisme prestasi itu dapat tercapai. Menurut Kompri (2017: 43) prestasi belajar adalah hasil belajar yang diperoleh dan tampak nyata pada setiap siswa berupa penambahan pengetahuan, timbulnya pengalaman baru, dan perubahan tingkah laku. Prestasi belajar yang dicapai siswa dipengaruhi oleh dua faktor utama 
yakni faktor dari dalam diri siswa itu dan faktor yang datang dari luar diri siswa atau faktor lingkungan. Faktor yang datang dari diri siswa terutama kemampuan yang dimilikinya. Faktor kemampuan siswa besar sekali pengaruhnya terhadap hasil belajar yang dicapai. Seperti dikemukakan oleh Clark bahwa hasil belajar siswa disekolah 70\% dipengaruhi oleh kemampuan siswa dan 30\% dipengaruhi oleh lingkungan (Kompri, 2017: 41). Indikator prestasi belajar ranah kognitif (Krathwolh, 2010: 100-102).

Tabel 2.1 Indikator Prestasi Belajar Ranah Kognitif

\begin{tabular}{|c|c|}
\hline Aspek & Indikator \\
\hline \multirow[t]{2}{*}{ 1. Mengingat } & 1.1. Mengenali \\
\hline & 1.2. Mengingat kembali \\
\hline \multirow[t]{7}{*}{ 2. Memahami } & 2.1. Menafsirkan \\
\hline & 2.2. Mencontohkan \\
\hline & 2.3. Mengklasifikasikan \\
\hline & 2.4. Merangkum \\
\hline & 2.5. Menyimpulkan \\
\hline & 2.6. Membandingkan \\
\hline & 2.7. Menjelaskan \\
\hline \multirow[t]{2}{*}{ 3. Mengaplikasikan } & 3.1. Mengeksekusi \\
\hline & 3.2. Mengimplementasikan \\
\hline \multirow[t]{3}{*}{ 4. Menganalisis } & 4.1. Membedakan \\
\hline & 4.2. Mengorganisasi \\
\hline & 4.3. Mengatribusikan \\
\hline \multirow[t]{2}{*}{ 5. Mengevaluasi } & 5.1. Memeriksa \\
\hline & 5.2. Mengkritik \\
\hline \multirow[t]{3}{*}{ 6. Mencipta } & 6.1. Merumuskan \\
\hline & 6.2. Merencanakan \\
\hline & 6.3. Memproduksi \\
\hline
\end{tabular}

Salah satu pondok pesantren yang memiliki program menghafal Al-Qur'an adalah Pondok Pesantren Tahfidh Putri Yanbu'ul Qur'an 2 Muria. Setiap santrinya memiliki kewajiban menghafal Al-Qur'an 15 juz selama menempuh pendidikan MTs. Target hafalan setiap santri berbeda-beda tergantung kemampuan yang dimiliki oleh santri tersebut. Pondok Pesantren Tahfidh Putri Yanbu'ul Qur'an 2 Muria menerapkan sistem di mana setiap santrinya tidak boleh memakai alat komunikasi dan setiap santri hanya memiliki satu kesempatan untuk setiap bulannya bertemu/dijenguk oleh orang tuanya berdasarkan ketentuan hari yang sudah ditentukan. Hal ini akan membantu santri untuk fokus dalam menghafal Al-Qur'an dan tidak memikirkan hal-hal yang bersifat duniawi. Fenomena ini mendorong peneliti untuk menguji apakah ada pengaruh antara menghafal Al-Qur'an dengan prestasi belajar matematika siswa MTs di Pondok Pesantren Tahfidh Putri Yanbu'ul Qur'an 2 Muria. 


\section{METODE}

\subsection{Prosedur Penelitian}

Jenis penelitian ini adalah penelitian kuantitatif. Pengambilan data dilaksanakan pada tanggal 22 Agustus 2019 di Pondok Pesantren Tahfidh Putri Yanbu’ul Qur'an 2 Muria, yang bertempat di Jalan Colo Gombong KM-1 di RT 1 RW II Desa Dukuh Waringin, Kecamatan Dawe, Kudus. Populasi dalam penelitian ini adalahsiswi MTs kelas VIII di Pondok Pesantren Tahfidh Putri Yanbu'ul Qur'an 2 Muria. Sampel dalam penelitian ini yaitu 30 siswi kelas VIII yang memiliki tingkat hafalan Al Qur'an yang tinggi, sedang dan rendah berdasarkan raport tahfidz. Dan kelas yang diambil adalah kelas VIII B. Teknik pengambilan sampel yang digunakan dalam penelitian ini adalah Disproportionate Stratified Random Sampling. Dalam cara disproporsional, penentuan sampel dilakukan tidak dengan mengambil proporsi yang sama bagi setiap subkelompok atau strata akan tetapi dimaksudkan untuk mencapai jumlah tertentu dari masing-masing strata (Azwar, 2011: 86-87). Di mana setiap stratanya 10 siswi, sehingga menghasilkan strata tinggi $=10$ siswi, strata sedang $=10$ siswi, strata rendah $=10$ siswi.

\subsection{Desain Penelitian}

Variabel dalam penelitian ini terdiri dari variabel bebas dan terikat. Variabel bebas atau indepedent variabel adalah hafalan Al Qur'an yang dilambangkan dengan " $X$ ". Sedangkan variabel terikat atau dependent variabel merupakan variabel yang akan dipengaruhi adalah prestasi belajar matematika di Pondok Pesantren Tahfidh Putri Yanbu'ul Qur'an 2 Kudus yang dilambangkan dengan "Y". Dalam penelitian instrumen yang digunakan berupa tes dan non tes. Untuk instrumen tes berupa tes tertulis prestasi belajar siswa dan non tes berupa lembar observasi hafalan Al-Qur'an. Teknik yang digunakan dalam pengumpulan data pada penelitian adalah dokumentasi. Dokumentasi digunakan untuk memperoleh informasi atau data tentang jumlah peserta didik keseluruhan sebagai populasi, daftar nama peserta didik yang menjadi responden dalam uji coba instrumen dan data nilai raport kelas VII semester 2 mata pelajaran matematika 2018/2019.

\subsection{Analisis dan Interpretasi Data}

\section{Uji Hubungan Antara Dua Variabel}

Mencari korelasi antara variabel $\mathrm{X}$ dan variabel Y dengan menggunakan teknik korelasi product moment, dengan rumus berikut.

$$
r_{x y}=\frac{N \sum X Y-\sum X \sum Y}{\sqrt{\left\{N \sum X^{2}-\left(\sum X\right)^{2}\right\}\left\{N \sum Y^{2}-\left(\sum Y\right)^{2}\right\}}}
$$

Keterangan:

$r_{x y}=$ koefisien korelasi antara skor butir soal $(\mathrm{X})$ dan total skor $(\mathrm{Y})$

$\mathrm{N}$ = banyaknya subjek

$\mathrm{X}=$ skor butir soal atau skor item pernyataan/pertanyaan

$\mathrm{Y}=$ total skor 
2. Uji Regresi Linier Sederhana

Mencari persamaan garis regresi dengan rumus regresi sederhana sebagai berikut.

$$
\begin{gathered}
Y=a+b X \\
a=\frac{\left(\sum Y\right)\left(\sum X^{2}\right)-\left(\sum X\right)\left(\sum X Y\right)}{n \sum X^{2}-\left(\sum X\right)^{2}} \\
b=\frac{n \sum X Y-\left(\sum X\right)\left(\sum Y\right)}{n \sum X^{2}-\left(\sum X\right)^{2}}
\end{gathered}
$$

3. Koefisien Determinasi

Mencari koefisien determinasi variabel $\mathrm{X}$ terhadap variabel $\mathrm{Y}$ dengan rumus:

$$
\mathrm{r}^{2}=\frac{J K R}{J K T}
$$

(Budiyono, 2016:255-26)

\section{HASIL PENELITIAN DAN PEMBAHASAN}

\subsection{Analisis Lembar Observasi Hafalan Al-Qur'an}

Dalam penelitian ini tingkat kemampuan hafalan Al-Qur'an siswa didapat dilihat dari hasil lembar observasi peneliti dalam kegiatan halaqoh di pondok tersebut dengan jumlah responden 30 siswa. Berdasarkan data peneliti untuk variabel kemampuan hafalan Al-Qur'an siswa nilai terendah yang dicapai sebesar 17 dan nilai tertinggi sebesar 100. Data distribusi frekuensi kemampuan hafalan Al-Qur'an siswa dapat dilihat pada Tabel 3.1.

Tabel 3.1. Distribusi Frekuensi Hafalan Al-Qur'an

\begin{tabular}{ccccc}
\hline No. & Kelas Interval & Frekuensi & Persentase Frekuensi (\%) & Kategori \\
\hline 1 & $11-40$ & 5 & 16,7 & Rendah \\
2 & $41-70$ & 9 & 30,0 & Sedang \\
3 & $71-100$ & 16 & 53,3 & Tinggi \\
& Jumlah & 30 & 100 & \\
\hline
\end{tabular}

Berdasarkan Tabel 3.1, siswa yang memiliki nilai kategori rendah sebanyak 5 siswa, sedangkan nilai kategori sedang sebanyak 9 siswa, dan nilai kategori tinggi sebanyak 16 siswa. Setelah hasil tersebut dihitung dengan melihat jumlah seluruh nilai dibagi dengan jumlah responden (2234 : 30) maka hasil yang diperoleh adalah 74,47 dan dibulatkan menjadi 74 . Dengan demikian, apabila dilihat dari tabel klasifikasi antara angka 71-100 yang berarti tingkat hafalan Al-Qur'an siswa kelas VIII B di MTs Yanbu'ul Qur'an 2 Muria termasuk dalam kategori tinggi.

\subsection{Analisis Data Prestasi Belajar Siswa}

Prestasi belajar siswa penghafal Al-Qur'an di MTs Yanbuq'ul Qur'an 2 Muria termasuk dalam kategori tinggi, hal ini dapat dilihat dari hasil prestasi belajar siswa di kelas yang menunjukkan bahwa siswa penghafal Al-Qur'an memiliki nilai dan intelegensi yang baik. Berdasarkan hasil penelitian yang dilakukan peneliti hanya ada 6 siswa yang memperoleh nilai dibawah KKM. 
Tabel 3.2. Distribusi Frekuensi Prestasi Belajar Siswa

\begin{tabular}{ccccc}
\hline No. & Kelas Interval & Frekuensi & Persentase Frekuensi (\%) & Kategori \\
\hline 1 & $26-50$ & 1 & 3,3 & Rendah \\
2 & $51-75$ & 9 & 30 & Sedang \\
3 & $76-100$ & 20 & 66,7 & Tinggi \\
\hline
\end{tabular}

Dari keterangan pada data Tabel 3.2 dapat kita lihat bahwa prestasi matematik siswa MTs Yanbuq'ul Qur'an 2 Muria tergolong sangat baik karena hanya ada beberapa siswa yang memperoleh nilai dibawah KKM dan nilai rata-ratanya adalah 81,2. Frekuensi terbanyak prestasi belajar siswa terletak pada kelas interval ketiga yang memiliki nilai 76-100 yaitu sejumlah 20 siswa. Apabila dilihat dari Tabel 3.2 kriteria nilai 81,2 berada diantara 76-100 yang berarti prestasi belajar matematika siswa MTs Yanbu'ul Qur'an 2 Muria termasuk dalam kategori tinggi.

\subsection{Analisis Data Akhir}

Analisis data akhir ini digunakan untuk mengetahui pengaruh hafalan Al-Qur'an terhadap prestasi belajar matematika siswa.

1. Uji Hubungan Antara Dua Variabel

$$
\begin{gathered}
H_{o} \text { : Kedua variabel } \mathrm{X} \text { dan } \mathrm{Y} \text { tidak ada korelasi }(\mathrm{r}=0) \\
\mathrm{H}_{\mathrm{a}} \text { : Kedua variabel } \mathrm{X} \text { dan } \mathrm{Y} \text { ada korelasi }(\mathrm{r} \neq 0)
\end{gathered}
$$

Untuk mengetahui ada tidaknya hubungan antara variabel $\mathrm{X}$ dan $\mathrm{Y}$ yaitu hubungan hafalan Al-Qur'an, dapat dicari dengan rumus korelasi product moment. Kriteria pengujinya adalah $H_{o}$ ditolak jika $r_{\text {hitung }}>r_{\text {tabel }}$ dengan taraf signifikasi 5\%. Dari perhitungan diperoleh

$r_{\text {hitung }}=0,589$. Sedangkan $r_{\text {tabel }}=0,361$. Karena $r_{\text {hitung }}>r_{\text {tabel }}$ yaitu $0,589>0,361$ sehingga $H_{o}$ ditolak. Jadi kesimpulannya bahwa kedua variabel $\mathrm{X}$ dan $\mathrm{Y}$ ada korelasi $(\mathrm{r} \neq 0)$. Artinya ada hubungan antara hafalan Al-Qur'an dengan prestasi belajar matematika.

2. Uji Regresi Linier Sederhana

Analisis regresi linier sederhana adalah hubungan secara linier atau satu variabel independen $(\mathrm{X})$ dengan variabel dependen $(\mathrm{Y})$. Analisis ini untuk mengetahui arah hubungan antara variabel independen dan dependen apakah positif atau negatif dan untuk memprediksi nilai dari variabel dependen apabila nilai variabel independen mengalami kenaikan atau penurunan.

Berdasarkan perhitungan, maka diperoleh $\mathrm{a}=56,7337$ dan $\mathrm{b}=0,3286$, sehingga diperoleh persamaan regresi linier sederhana yaitu:

$$
\begin{aligned}
& \widehat{Y}=a+b X, \\
& \widehat{Y}=56,7337+0,3286 X .
\end{aligned}
$$

Koefisien $b$ menyatakan rata-rata variabel $\mathrm{Y}$ untuk setiap perubahan satu variabel $\mathrm{X}$ sebesar satu unit. Artinya jika hafalan Al-Qur'an bertambah 1 satuan maka nilai prestasi belajar akan bertambah sebesar 0,3286.

3. Koefisien Determinasi.

$H_{o}$ : Tidak ada hubungan hafalan Al-Qur'an dengan prestasi belajar matematika siswa. $H_{a}$ : Ada hubungan hafalan Al-Qur'an dengan prestasi belajar matematika siswa. 
Berdasarkan perhitungan, diperoleh koefisien determinasi $r^{2}=0,347$ atau sebesar 34,7\%. Ini berarti meningkatnya atau menurunya prestasi belajar matematika siswa sebesar 34,7\%. Maka $H_{o}$ ditolak dan $H_{a}$ diterima. Jadi kesimpulannya bahwa prestasi belajar matematika siswa 34,7\% ditentukan oleh hafalan Al-Qur'an dan 65,3\% ditentukan oleh faktor lain.

Berdasarkan analisis data yang telah diuraikan pada hasil penelitian, dapat diketahui bahwa terdapat pengaruh positif antara hafalan Al-Qur'an terhadap prestasi belajar matematika siswa. Hasil penelitian ini sejalan dengan hasil penelitian yang dilakukan oleh (Romi, 2018) didapat bahwa terdapat perbedaan prestasi belajar matematika antara siswa yang menghafal AlQur'an dengan siswa yang tidak menghafal Al-Qur'an. Prestasi belajar matematika siswa yang mengikuti program menghafal Al-Qur'an lebih tinggi dari pada siswa yang tidak mengikuti program menghafal Al-Qur'an. Perbedaan positif tersebut menunjukkan bahwa semakin tinggi persentase siswa yang menghafal Al-Qur'an maka semakin tinggi pula prestasi belajarnya, dan sebaliknya semakin rendah persentase siswa yang menghafal Al-Qur'an maka semakin rendah pula prestasi belajar matematika siswa. Hal ini sejalan dengan penelitian yang dilakukan oleh (Mahmudah, 2016) yang menyebutkan bahwa variabel hafalan Al-Qur'an memberikan pengaruh terhadap hasil belajar siswa sebesar 75,6\%, sedangkan $24,4 \%$ dipengaruhi oleh faktor-faktor yang mempengaruhi hafalan Al-Qur'an baik faktor eksternal maupun internal. Berdasarkan penelitian yang dilakukan oleh Kamal (2017) yang menyebutkan bahwa program menghafal yang dilakukan sebagian siswa dapat mempengaruhi keberhasilan dan prestasi belajar siswa, bahkan menghafal mungkin dapat dikatakan menjadi faktor yang penting dalam prestasi belajar siswa. Sebab dari menghafal otak anak langsung belajar mengasah kemampuan untuk menghafal dari yang dilihat dan dibaca. Dengan demikian anak akan terbiasa menghafal sesuatu yang dibaca dan didengar. Ini juga mempengaruhi kecepatan otak anak dalam memproses mata pelajaran yang diterimanya.

Aktivitas menghafal Al-Qur'an dan pengaruhnya terhadap prestasi belajar terdapat pengaruh yang signifikan (Ginanjar, 2017). Sedangkan berdasarkan penelitian yang pernah dilakukan oleh (Marza, 2017) menyebutkan bahwa remaja penghafal Al-Qur'an, sebagian besar mampu meregulasi diri dengan baik. Dampak yang dirasakan remaja ketika mampu meregulasi diri dengan baik antara lain mampu menghafal Al-Qur'an dengan baik dan benar, mendapatkan hafalan yang lebih banyak, mampu berprestasi di bidang akademik maupun non akademik.

Dari hasil persamaan regresi yaitu $\widehat{Y}=56,733+0,3286 X$ dimana $Y$ adalah prestasi belajar matematika dan X adalah hafalan Al-Qur'an .Persamaan regresi tersebut dapat diartikan bahwa untuk setiap variabel $\mathrm{X}$ bertambah satu unit, maka variabel $\mathrm{Y}$ bertambah 0,3286. Koefisien determinasi atau besarnya sumbangan pengaruh $\mathrm{X}$ terhadap $\mathrm{Y}$ adalah 0,347 atau sebesar 34,7\%. Ini berarti kontribusi hafalan Al-Qur'an terhadap prestasi belajar matematika sebesar $34,7 \%$ sedangkan $65,3 \%$ ditentukan oleh faktor lain.

\section{SIMPULAN}

Berdasarkan hasil lembar observasi yang dilakukan oleh peneliti bahwa hafalan AlQur'an mencapai rata-rata 74. Dengan demikian sesuai dengan data yang ada, hafalan AlQur'an di Pondok Pesantren Tahfidh Putri Yanbu'ul Qur'an 2 Muria berada pada kategori tinggi. Prestasi belajar matematikasiswa kelas VIII B di MTs Yanbu'ul Qur'an 2 Muria 
termasuk dalam kategori tinggi dengan nilai rata-rata 81,2.Terdapat pengaruh positif dan signifikan antara hafalan Al-Qur'an terhadap prestasi belajar matematika siswa MTs Yanbu'ul Qur'an 2 Muria, hal ini ditunjukkan dengan nilai $r$ sebesar 0,589 dengan sumbangan efektif sebesar $34,7 \%$ sedangkan $65,3 \%$ ditentukan oleh faktor lain.

\section{DAFTAR PUSTAKA}

Azwar, S. (2011). Metodologi Penelitian. Yogyakarta: Pustaka Pelajar Offset.

Budiyono. (2016). Statistika. Surakarta. UNS Press.

Ginanjar, M. (2017). Aktivitas Menghafal Al-Qur'an dan Pengaruhnya Terhadap Prestasi Akademik Mahasiswa. Jurnal Pendidikan Islam, 06.

Kompri. (2017). Belajar Faktor-Faktor yang Mempengaruhinya. Jambi: Media Akademi.

Mahmudah. (2016). Analisis Pengaruh Hafalan Al-Qur'an Terhadap Prestasi Belajar Siswa di MA AL-Amiriyyah BlokAgung Banyuwangi. Jurnal Pendidikan, Komunikasi dan Pemikiran Hukum Islam, 08.

Mustofa, K. (2017). Pengaruh Pelaksanaan Program Menghafal Al-Qur'an Terhadap Prestasi Belajar Siswa. Jurnal Pendidikan Islam, 06.

R.Krathwohl, L. W. (2010). Kerangka Landasan Pembelajaran, Pengajaran dan Asesmen. Yogyakarta: Pustaka Pelajar.

Romi, Y. A. (2018). Perbedaan Prestasi Belajar Matematika Antara Siswa yang Mengikuti dan Tidak Mengikuti Program Menghafal Al-Qur'an. Fakultas Psikologi, 12, 1-10.

Shirazy, M. A. (2018). Kamus Arab - Indonesia. Victory Inti Cipta.

Subandi, L. C. (2010). Psikologi Santri Penghafal Al-Qur'an. Yogyakarta: Pustaka Pelajar. 